\title{
pH自動制御におけるプロセス特性
}

（昭 和 33 年 2 月 17 日受 理）

\section{岡田辰三・西朋太・高橋 寛*}

$\mathrm{pH}$ 制御の場合の制御対象の特性に相当する滞留槽中の $\mathrm{pH}$ 反応速度を調へ，同時に，滞留槽のるつ性質について考察 した。まず, 強酸一強塩基系について, 完全混合型とみなされる滞留槽中の $\mathrm{pH}$ 沁答性を調べ, 最終平衡値の綬沺指数の 大きい場合を除いて，ほぼ理論式で表わされることをみた。実験值と計算値の一致しなくなる限界は， pH一時間の計算曲

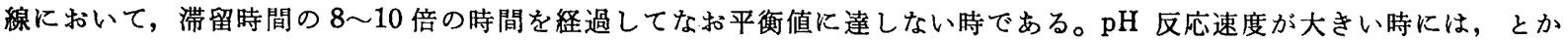
く滞留時間を大きくすることを考光勝ちであるが，被調節液の $\mathrm{pH}$ 特性によっては，ほとんど滞留時間によって影飶され ないことがあるから注意を要する。このよ5な時は，多段滞留槽を用いるのが望ましく，そのための設計上の指針を提出 した。

\section{I. 緒言}

一般に，自動制御を成功に導くには，プロセスの特性と制御系 の特性を適当㳊組合わす必要がある。 $\mathrm{pH}$ 制御においては，プロ セス液の $\mathrm{pH}$ 変化に対応して操作系が働き，訂正動作を起すた め, $\mathrm{pH}$ 負荷変化の大きさとその反応速度とが, $\mathrm{pH}$ 制御の重要 な因子となる。

濃度変化の大ささ速度をさめるものは，イオン間反応におい ては, 滞留槽の容量と被調節液および調節液の流量であり, 容量 が大きく流量が小さいほど，濃度の変化速度は招そくなる。すな わち, 滞留槽は, 負荷の突変を指数関数変化汇転换する機能を有 するるのである。しかる，自動制御の立場からみれば，プロセス の反応速度が小さいほど，負荷変化が起っても制御変数を一定に 保ち易い。したがって，自動制御上；プロセス容量は，ある程度 大きいことが望ましいものであり，また，これによって，自動制 御の制御性が左右されるといっても過言ではない。また，とくに $\mathrm{pH}$ 制御の場合，滞留槽と同じ作用をするるのとして，溶液の緩 衝指数※1がある。

ここでは, $\mathrm{pH}$ 平衡が突然破れた時の $\mathrm{pH}$ 值の変化速度を調べ る過渡応答法により, 緩衝指数と $\mathrm{pH}$ 反応速度との定量的関係を 求め, $\mathrm{pH}$ 変化の異常性を指摘するとともに, 滞留槽のもつ性質 について明らかにする。

\section{II. 実 験 装 置}

第 1 困は，実験装置の大略を示し，溶液 I , II の定水位槽，カ キマゼ槽検出器，增幅器および記録計よりなる。

$\mathrm{A} ， \mathrm{~A}^{\prime}$ は，それぞれ溶液 I， II の供給槽， B， B' II の定水位槽で， $\mathrm{C} ， \mathrm{C}^{\prime}$ は流量計である。液分散器 $\mathrm{E}$ は，径 4 $\mathrm{mm}$ のガラス管の先端を球形にし，その表面に，径 $1 \mathrm{~mm}$ の孔 を 8 個あけている。カキマゼ槽は，直径 $13 \mathrm{~cm}$ ，高さ $20.5 \mathrm{~cm}$ のガラス管で，夜の流出する下部は円錐型である。とくに, $\mathrm{pH}$ 変化は，カキマゼ槽中の short circuiting によって，不規則な変 化を生じ易いので，かきまぜは十分行う必要があった。

すでに報告1)したように，ガラス電極 Jは，溶液の性質により， 異なる $\mathrm{pH}$ 応答性を示すため，噴出器 $\mathrm{G}$ を使用して，なるべく検

† 本報を「ガラス麗極による pH 調節に関する基碟的研究 (第 3 報)」とする。

* 京都大学工学研究所：京都市左京区吉田.

※1 緩衝指数 $\sigma=\Delta \mathrm{pH} / \Delta \phi, \Delta \phi$ は添加した調節剤量を表わす。

1) 岡田, 西, 高橋, 工化 $61 ， 840$ (1958),
策 1 図実験 装置

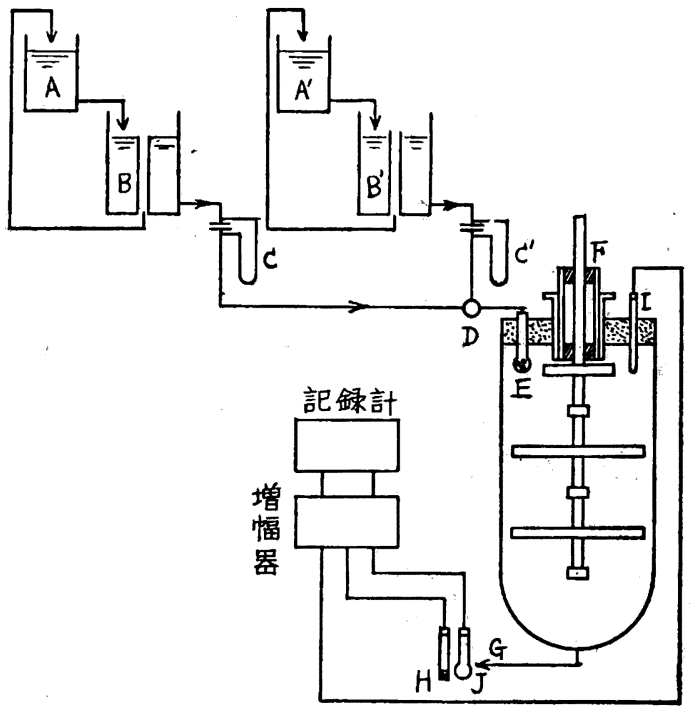

出おくれを小さくした。

溶液の温度は, $20 \sim 23^{\circ} \mathrm{C} て ゙$, 抵抗温度計 I により，自動温度 補償を行った。また，実験に使用した溶液は， $\mathrm{HCl}-\mathrm{NaOH}$ の強 酸一強塩基系である。

操作は，まず，カキマゼ翼を一定速度で回転させながら溶液 I を定水位槽 $\mathrm{B} ， コ ッ ク \mathrm{D}$ ，液分散器 $\mathrm{E}$ 経て，カキマゼ槽に送 る。滞留時間を一定にするために，カキマゼ槽内は常に溶液で充 満しており，またカキマゼ棒と支持ゴム栓の間から液が溢出する のを防ぐため，図のよ5に注射筒 $\mathrm{F}$ を使用した。送入液量が一定 になった後, 三方コック Dを手早く切換えて，溶液 IIをカキマゼ 槽に入れる。

記録は，すべて，ペン速度 1 秒の電子管式記録計から読みとっ た。また，カキマゼ槽の内部扣くれが存在するため，記録計に変 化が表われた時を，時間零とした。

\section{III. 実験結果および考察}

第 2 図は, $\mathrm{pH} 1 \rightleftarrows \mathrm{pH} 4$ の応答結果で, $\mathrm{pH} 1 \rightarrow \mathrm{pH} 4$ の場合 には，滞留時間が 6.25 分であるにもかかわらず，非常におそい 応答を示す。しかも，直線状応答を示し，あたかも自己制御性の ない系のような挙動を示す。普通，滞留槽における濃度変化を取 扱 5 場合，滞留時間でその特性を表わし，滞留時間に等しい時間 だけ経過すると，その濃度変化率は $63.3 \%$ 亿達する。しかる に, $\mathrm{pH} 1 \rightarrow \mathrm{pH} 4$ の応答では, 滞留時間 6.25 分で, $\mathrm{pH}$ 変化率 
は $16.6 \%$ ，逆に $\mathrm{pH}$ 変化率が $63.3 \%$ に達するには， 26.8 分の 長時閐を要する。これは, 普通の濃度応答で, 容量の非常に大き いプロセスに相当する。これに対し, $\mathrm{pH} 4 \rightarrow \mathrm{pH} 1$ の変化では, 非常に速い応答を示し（滞留時間だけ経過すると，すでに $98 \%$ の $\mathrm{pH}$ 変化率を示す), 容量の小さい場合に相当する。

第 2 図 $\mathrm{pH} 1 \rightleftarrows \mathrm{pH} 4$ の応答

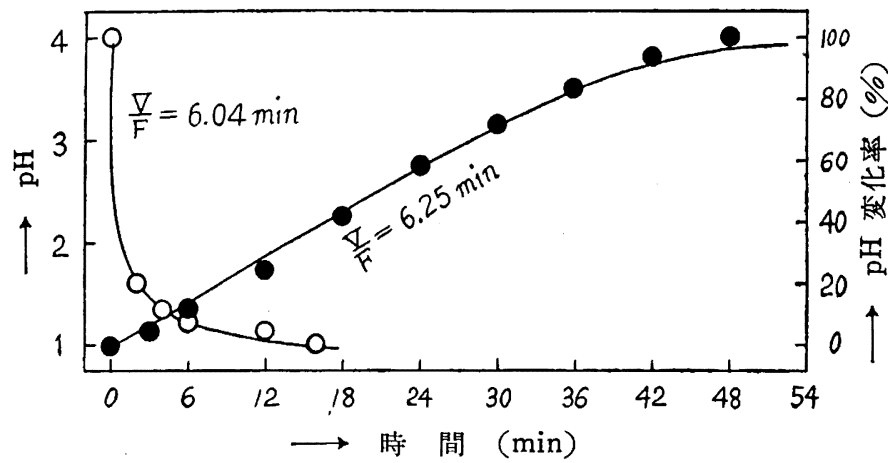

後述の実験結果から総合して，これらの現象は，単に濃度変化 を $\mathrm{pH}$ 変化に換算するだけでは説明出来ず，溶液の $\mathrm{pH}$ 特性その ものが関係している。

いま, 完全混合型滞留槽について, 初濃度 $b_{0}$ なる塩基が $b_{\infty}$ に変化する場合, 濃度 $b$ の変化は

$$
b=b_{\infty}+\left(b_{0}-b_{\infty}\right) \exp \left\{-\frac{F}{V} t\right\}
$$

で表わされる。ここに $V$ は滞留槽の容量, $F$ は流量, $t$ は時間 を表わす。したがって，V/F が滞留時間になる。

一方, 強酸一強塩基系の場合, 次式が成立する。

$$
H-\frac{K_{\mathrm{w}}}{H}=a-b
$$

ただし， $a$ は酸の濃度， $H$ は水素イオン濃度を表わし，また， 水の熱力学的電離定数を $k_{\mathrm{W}}$ とすれば, $k_{\mathrm{W}} \cdot a_{\mathrm{H}_{2} \mathrm{O}}=K_{\mathrm{W}} \cdot f_{\mathrm{H}} \cdot f_{\mathrm{OH}}$ $\left(a_{\mathrm{H}_{2} \mathrm{O}}\right.$ は水の活量, $f$ は活量係数) である。

(2) 式より

$$
b_{0}=a-\left(H_{0}-\frac{K_{\mathrm{w}}}{H_{0}}\right), \quad b_{\infty}=a-\left(H_{\infty}-\frac{K_{\mathrm{w}}}{H_{\infty}}\right)
$$

なる故，（3）式を（1）式に代入し，次式がえられる。

$$
\begin{aligned}
H-\frac{K_{\mathrm{w}}}{H} & =\left(H_{\infty}-\frac{K_{\mathrm{w}}}{H_{\infty}}\right)+\left[\left(H_{0}-\frac{K_{\mathrm{w}}}{H_{0}}\right)\right. \\
& \left.-\left(H_{\infty}-\frac{K_{\mathrm{w}}}{H_{\infty}}\right)\right] \exp \left\{-\frac{F}{V} t\right\}
\end{aligned}
$$

実験は，なるべく完全混合型になるよろな状態で行っており， この（4）式を使用して, 流系滞留槽中の $\mathrm{pH}$ 変化が定量的に説 明できるかど5か考察するために，各実験結果に，(4) 式の計 算値を併記した。

第 2 図からわかるように, pH 4 $\rightarrow \mathrm{pH} 1$ の場合には, 理論值と よく一致するが, $\mathrm{pH} 1 \rightarrow \mathrm{pH} 4$ の場合には若干偏倚する。とくに, 応答の立上り，および応答の終りで，大きく偏倚するよ り，これは滞留槽自体が，完全混合型でないことによるすのと考 えられる。

第 3 図は, $\mathrm{pH} 1 \rightleftarrows \mathrm{pH} 7$ の応答結果である。 $\mathrm{pH} 7 \rightarrow \mathrm{pH} 1$ の 時は応答速く，しか子計算值とかなりよく一致する。これに対

$※ 2$ 後述の (1) 式より $t=V / F$ (滞留時間) と拈けば, $\left(b_{\infty}-\right.$ $b) /\left(b_{\infty}-b_{0}\right)=1 / e_{\text {。 }}$ 故に, $\left(b-b_{0}\right) /\left(b_{\infty}-b_{0}\right)$ (濃度变化率) $=$ $1-1 / e=0.633$ 。
第 3 図 $\mathrm{pH} 1 \rightleftarrows \mathrm{pH} 7$ の応答

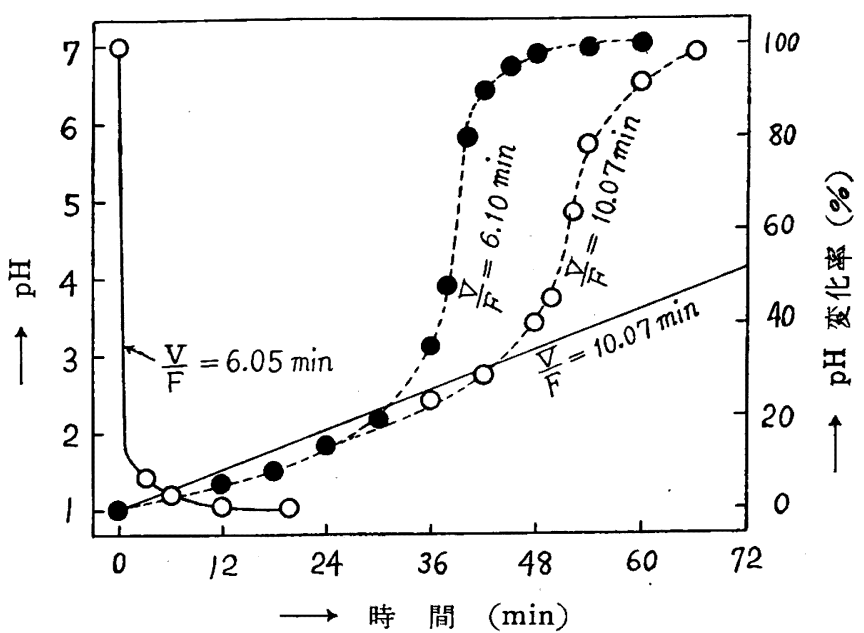

し, $\mathrm{pH} 1 \rightarrow \mathrm{pH} 7$ の変化では, $\mathrm{S}$ 状応答を示し, 計算値と大きな 差を示す。

（4）式によれば，図中に示すよ5に，ほとんど直線状に変化 するはずである。この原因として，次のように考えることが出来 る。（4）式を導く際, 条件として, 時間無限大で, 最終平衡值 に到達すると考えているが，実際には，ある有限時間で平衡值に 達するはずである。しかも， $\mathrm{pH} 7$ 付近では，緩衝指数が大きい ため，塩基濃度の理論値と実際値との僅かな差により，大きな $\mathrm{pH}$ 変化を生ずる。このため, $\mathrm{S}$ 状応答を示すよ にになるすのと 考えられる。

また，第 2 図扣よび第 3 図からわかるよ5に，平衡值 $\mathrm{pH} 4$ お よび pH 7 で，その平衡時間が，あまり变わらないのは，pH 4 お よび $\mathrm{pH} 7$ に変化させるに必要な塩基量に，ほとんど差がないた めである。

実際に，S状応答を示すよ5になる最終平衡値を確認するた め, $\mathrm{pH} 1 \rightarrow \mathrm{pH} x$ なる応答について実験してみた。その結果を第 4 図に示す。pH 5 まではほとんど直線状応答をするが, pH5.5 以上になると， $\mathrm{S}$ 状応答を示すようになる。種々の実験から，平 均的にみて, 最もおそい応答を示するのでも, 帯留時間の 8〜10 倍の時間が経過すれば, 平衡值に達するようであり, 理論的に, これだけの時間が経過しても，なお平衡値に達しない場合には， $\mathrm{S}$ 状応答を示してくるよ5になる。

第 4 図最終平衡 $\mathrm{pH}$ 值と応答の関係

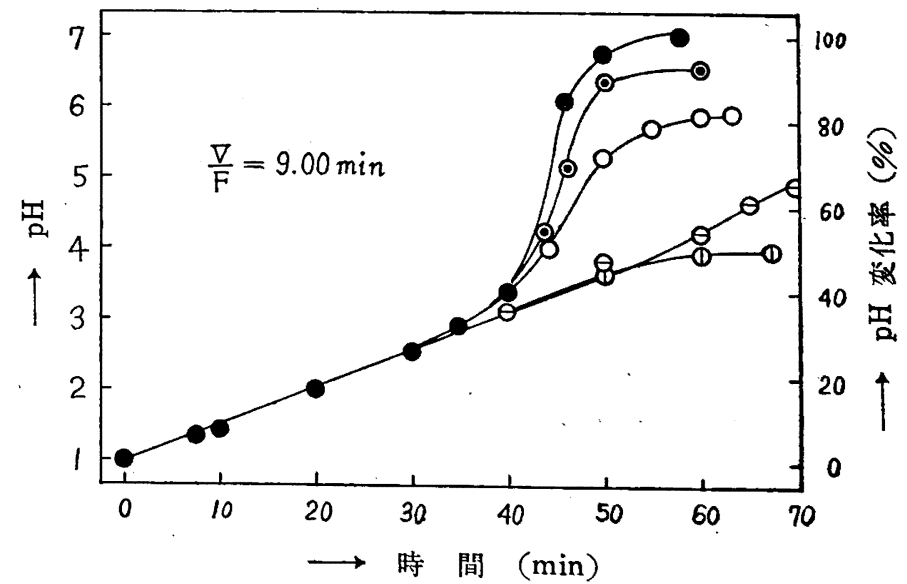

第 5 図は，変化範囲を広くして，pH $1 \rightleftarrows \mathrm{pH} 12$ にしたもの である。第 5 図からわかるように，初めの $\mathrm{pH}$ 值が， $\mathrm{pH} 12$ のよ 
5に，強アルカリ範囲にあっても，最終平衡值が $\mathrm{pH} 1$ のように 強酸性範囲にある時は，応答が非常に速くなる。 $\mathrm{pH} 1 \rightarrow \mathrm{pH} 12$ の 時は，S状応答を示すが，むしろむだ時間のあるピストン流と考 えてよい压どである。この他, $\mathrm{pH}$ 変化範围を種々変えて実験し てみたが，いずれる（4）式とほぼ合致する結果がえられた。

第 5 図 $\mathrm{pH} 1 \rightleftarrows \mathrm{pH} 12$ の応答

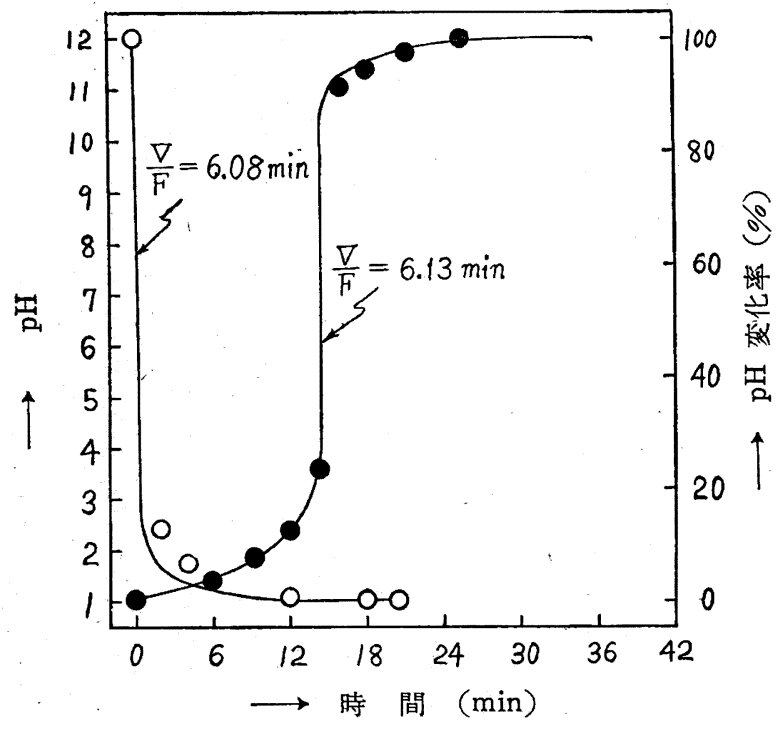

IV. 滞留時間の影響

第 6 図は，pH $1 \rightleftarrows \mathrm{pH} 4$ の応答について，滞留時間の影響を 調べたものである。 $\mathrm{pH} 1 \rightarrow \mathrm{pH} 4$ の場合には, 滞留時間が大きく 影響するが， $\mathrm{pH} 4 \rightarrow \mathrm{pH} 1$ の場合には，あまり変わらない。これ は（4）式からす期待されるところである。とくに，応答の速い $\mathrm{pH} 4 \rightarrow \mathrm{pH} 1$ の上らな場合，反応速度を小さくする目的で，滞留 時間を大きくする時には，帯留時間を相当大きくしないかぎり， 目的を達することが出来ない。したがって，滞留時間を大きくし て $\mathrm{pH}$ 反応速度がほとんど変わらないからといって, 調節器の比 例帯をそのままにして和くと，かえって，制御結果のサイクリン グが大きくなることがある。これは， $\mathrm{pH}$ 反応速度がほとんど減 少しないで，滞留槽の内部拉くれが增加し，そのために，比例带 がせまくなりすぎることとよる。

第 6 図 滞留時間の応答に及ぼす影響

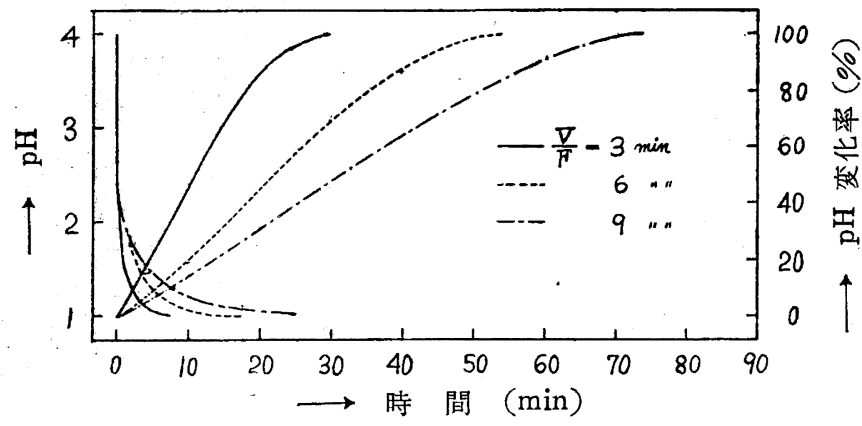

v. pH 反応速度 ${ }^{3}$ の計算

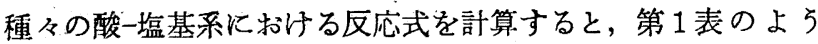
になる。ただし，滞留槽は完全混合型とみなし，また表中の酸一

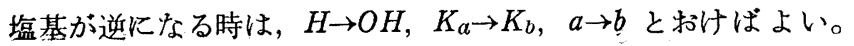
※3 $\mathrm{pH}$ 值に関するプロセス反応速度を意味する。
第 1 表 流系滞留槽中の水素イオン濃度変化

$$
\begin{aligned}
& \left(H-\frac{K \mathbb{w}}{H}\right)-X(H)=\left(H_{\infty}-\frac{K \mathbb{w}}{H_{\infty}}\right)-X\left(H_{\infty}\right)+\left[\left(H_{0}-\frac{K w}{H_{0}}\right)-X\left(H_{0}\right)\right. \\
& \left.-\left(H_{\infty}-\frac{K \mathrm{w}}{H_{\infty}}\right)+X\left(H_{\infty}\right)\right] \times \operatorname{xp}\left\{-\frac{F}{V} t\right\}
\end{aligned}
$$

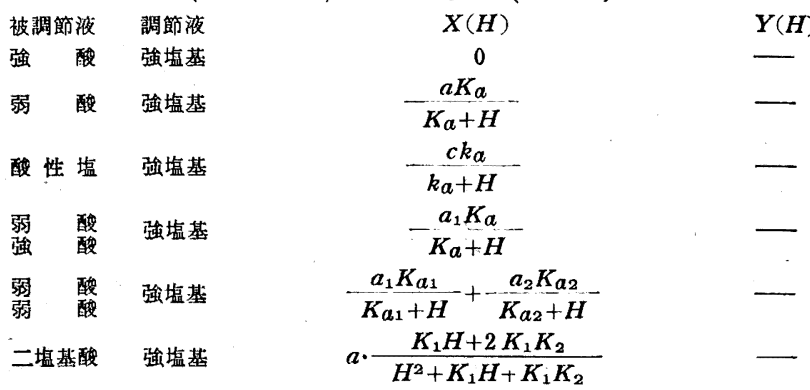

$$
\begin{aligned}
& \text { 三㙁基酸 强塩基 } \quad a \cdot \frac{1+2 \frac{K_{2}}{H}+3 \frac{K_{2} K_{3}}{H^{2}}}{1+\frac{H}{K_{1}}+\frac{K_{2}}{H}+\frac{K_{2} K_{3}}{H^{2}}} \\
& \text { 弱 酸* 弱㙁基* } \frac{a K_{a}}{K_{a}+H} \quad 1+\frac{K \mathrm{w}}{K_{a}} \cdot \frac{1}{H}
\end{aligned}
$$

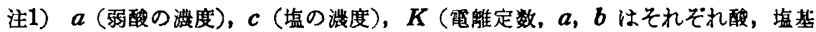
を表わす)

$K_{1} K_{2} K_{3} \cdots$ (多埴基酸の第 $1 ， 2,3 \cdots$ 電離定数)， $k_{a}$ (塭の加水分解定数）

注2）熱力学的電離定数を $k$ ，活量係数を質量法則の形飞かいたものを $k f$ とすれ ば $k=K \cdot k f$. また水秦イオン活量 $a \mathrm{H}=\rho_{\mathrm{H}} \cdot \boldsymbol{H}$

* $\quad Y(H)\left[\left(H-\frac{K w}{H}\right)-X(H)\right]=Y\left(H_{\infty}\right)\left[\left(H_{\infty}-\frac{K w}{H_{\infty}}\right)-X\left(H_{\infty}\right)\right]$ $+\left\{Y\left(H_{0}\right)\left[\left(H_{0}-\frac{K w}{H_{0}}\right)-X\left(H_{0}\right)\right]-Y\left(H_{\infty}\right)\right.$

$\left.\times\left[\left(H_{\infty}-\frac{K w}{H_{\infty}}\right)-X\left(H_{\infty}\right)\right]\right\} \exp \left\{-\frac{F}{V} t\right\}$

なお，実際の計算に当たっては，省略できる項が存在するため， 式の形ほど煩雑ではない。

また，溶液の特性を簡単に数式化出来ない場合には，次のよう にして，pH 反応速度を計算することが出来る。まず，取扱 5 被 調節液の $\mathrm{pH}$ 特性すなわち滴定曲線を求める。被調節液の初め の $\mathrm{pH}$ 值 $\mathrm{pH}_{0}$ および平衡 $\mathrm{pH}$ 值 $\mathrm{pH}_{\infty}$ は既知值なる故, これに 必要な調節剤量 $b_{0}, b_{\infty}$ がわかる。したがって，(1) 式あるいは 不完全混合型滞留槽の濃度応答曲線から, 時間 $t$ をさめれば $b か ゙$ わかる故，滴定曲線より，これに相当する $\mathrm{pH}$ 值を読みとれば， $\mathrm{pH}-t$ 曲線を描くことが出来る。ただし，最終平衡値の緩衝指数 が，非常に大きい時には，計算と一致せず，第 3 図あるいは，第 4 図のような傾向をとるので，注意を要する。

なお，槽内で化学反応が起る場合については, Mason, Piret ${ }^{2)}$ が完全混合型帯留槽中の濃度応答式を計算しており，これを利用 して，上記の方法により， $\mathrm{pH}$ 反応速度を求めればよい。

実際の工業的規模の滞留槽では, 完全混合型の場合は少なく, 多かれ少なかれ不完全混合型になる。流系滞留槽中の混合の程度 あるいは，濃度応答曲線を知るには，実験によらなければならな い。っしかし，場合によってて，永田 ${ }^{3}$ 注）らの実験式を利用すれ ば，簡単に，濃度応答曲線を計算することが出来るであろら。

また，設定点前後で，緩衝指数の異なることがしばしばあるの で，プロセス特性を求める時には，設定点を中心にして，正およ び負のインパルスを加え, 検討するのが妥当と考えられる。

2) D. R. Mason, E. L. Piret, Ind. Eng. Chem. 42, 817 (1950); 43, 1210 (1951).

3）永田，江口ら，化学工学 17, 387 (1953)；21，784(1957); 矢木, 宮内, 化学工学 17,382 (1953). 


\section{VI. 正弦波状入力に対する滞留槽中の pH 変化}

実際の制御プロセスに打ける $\mathrm{pH}$ 変化状態は，甚だ不規則なる のであるが，ここでは $\mathrm{pH}$ 制御の立場から，滞留槽のもつ性質を 明らかにする目的で，正弦波状入力が滞留槽に入った時の出力 $\mathrm{pH}$ 変化について考察してみた。

また, 以下の結果は滞留槽を $\mathrm{pH}$ 制卸後の変化を緩衝化する目 的に使用する時にも適用されうるものである。

いま, 塩基濃度 (調節剤) が次式で示されるような変化をして いるとする。

$$
b_{\infty}=\left(b^{\prime}{ }_{\mathrm{B}}-b_{\mathrm{s}}\right) \sin \omega t+b_{\mathrm{s}}
$$

ただし， $b_{B}$ は設定点に拊ける塩基濃度で, 入力 $b_{\infty}$ は, 振幅 $\left(b^{\prime}-b_{\mathrm{B}}\right)$, 円振動数 $\omega$ で正弦波状变化をしている。

一方，Vなる容量の滞留槽に， $B_{0}$ なる濃度の塩基を含む被調 節液が， $F_{0}$ なる流量で流れて扣り，これに濃度 $B_{1}$ の塩基を $F_{1}$ なる流量で添加するものとし，塩基濃度 $b$ のみの変化に注目すれ ば，次式が成立する。

$$
V \cdot \frac{\mathrm{d} b}{\mathrm{~d} t}=F_{0} B_{0}+F_{1} B_{1}-\left(F_{0}+F_{1}\right) b
$$

故に

$$
\frac{V}{F_{0}+F_{1}} \cdot \frac{\mathrm{d} b}{\mathrm{~d} t}+b=\frac{F_{0} B_{0}+F_{1} B_{1}}{F_{0}+F_{1}}
$$

（7）式右辺は， $t \rightarrow \infty$ の時の $b$ の值すなわち最終平衡値で, これを $b_{\infty}$ とおき，(5)，（6）式より，定常状態に打ける出力 值 $b_{\dot{s}}^{e}$ を求めると

$$
\begin{aligned}
& b_{\mathrm{s}}^{e}=b_{\mathrm{b}}+\frac{b_{\mathrm{s}}^{\prime}-b_{\mathrm{s}}}{\sqrt{1+\left(\omega \cdot \frac{V}{F_{0}+F_{1}}\right)^{2}}} \\
& \phi=\tan ^{-1}\left(\omega \cdot \frac{V}{F_{0}+F_{1}}\right)
\end{aligned}
$$

ここで，申は位相おくれを表わす。

（8）式は，程基濃度の gain を表わすもので，被調節液の $\mathrm{pH}$ 特性がわかれば，その関媇を（8）式に代入することにより，周 波数特性を計算することが出来る。たとえば，強酸一強塩基系の 場合には（2），（8）式より, 設定点に対し正方向では

$$
\begin{aligned}
& \frac{1}{\sqrt{1+\left(\omega \cdot \frac{V}{F_{0}+F_{1}}\right)^{2}}} \\
& =\frac{1-10^{-\left(\Delta \mathrm{pH}^{+}\right)^{\prime}}}{1-10-\Delta \mathrm{pH}^{+}} \cdot \frac{1+10^{\mathrm{pHs}+\left(\mathrm{pHs}^{+}\right)-\mathrm{pKW}}}{1+10 \mathrm{pHs}^{\mathrm{pHH} \mathrm{s}^{+}-\mathrm{pK} \mathrm{w}}}
\end{aligned}
$$

設定点に対し負方向では

\begin{tabular}{|c|c|c|c|c|}
\hline \multirow{2}{*}{$\omega \cdot \frac{V}{F_{0}+F_{1}}$} & \multicolumn{2}{|c|}{$\begin{array}{l}\text { 流最変動率 } \mathrm{A}^{+}=\mathrm{A}^{-}=0.009 \\
\Delta \mathrm{pH}^{+}=1.02 \quad \Delta \mathrm{pH}^{-}=0.28\end{array}$} & \multicolumn{2}{|c|}{$\begin{array}{c}\mathrm{A}^{+}=\mathrm{A}^{-}=0.02 \\
\Delta \mathrm{pH}^{+}=7.4 \quad \Delta \mathrm{pH}^{-}=0.5\end{array}$} \\
\hline & $\left(\Delta \mathrm{pH}^{+}\right)^{\prime}$ & $\left(\Delta \mathrm{pH}^{-}\right)^{\prime}$ & $\left(\Delta \mathrm{pH}^{+}\right)^{\prime}$ & $\left(\Delta \mathrm{pH}^{-}\right)^{\prime}$ \\
\hline 0.1 & 0.98 & 0.27 & 2.40 & 0.48 \\
\hline 1 & 0.44 & 0.21 & 0.53 & 0.40 \\
\hline 10 & 0.04 & 0.04 & 0.08 & 0.05 \\
\hline 100 & 0.00 & 0.00 & 0.01 & 0.00 \\
\hline
\end{tabular}

$$
\begin{aligned}
& \frac{1}{\sqrt{1+\left(\omega \cdot \frac{V}{F_{0}+F_{1}}\right)^{2}}} \\
& =\frac{1-10\left(\Delta \mathrm{pH}^{-}\right)^{\prime}}{1-10 \Delta \mathrm{pH}^{-}} \cdot \frac{1+10 \mathrm{pHs}^{2}+\left(\mathrm{pHs}^{-}\right)^{\prime}-\mathrm{pKw}}{1+10 \mathrm{pHs}+\mathrm{pHs}^{-}-\mathrm{pKw}}
\end{aligned}
$$

ただし, +, 一の符号は, 設定点に対し, 正, 負方向の值を表 わし, $\Delta \mathrm{pH}_{\mathrm{8}}{ }^{+}$(入力 $\mathrm{pH}$ 正誤差) $=\mathrm{pH}_{\mathrm{8}}{ }^{+}-\mathrm{pH}_{\mathrm{8}},\left(\Delta \mathrm{pH}^{+}\right)^{\prime}$ (出力 $\mathrm{pH}$ 正誤差 $)=\left(\mathrm{pH}_{\mathrm{s}}^{+}\right)^{\prime}-\mathrm{pH}_{\mathrm{s}}, \Delta \mathrm{pH}_{\mathrm{s}}^{-}$(入力 $\mathrm{pH}$ 負誤差 $)=\mathrm{pH}_{6}-\mathrm{pH}^{-}$， $\left(\Delta \mathrm{pH}^{-}\right)^{\prime}$ (出力 $\mathrm{pH}$ 負誤差) $\left.=\mathrm{pH}_{\mathrm{f}}-\left(\mathrm{pH}_{\mathrm{s}}\right)^{\prime}\right)^{\prime}$ である。

$$
\text { 第 } 2 \text { 表 }
$$

(10)，(11）式に基く計算結果の一例を第 2 表に示す。これは, $\mathrm{pH} 1$ の強酸を $\mathrm{pH} 3$ に調節する場合について, その流量変動率》 を $0.9 \%, 2.0 \%$ にした時の出力 $\mathrm{pH}$ 誤差を示す。 $A^{+}=A^{-}=2.0$ \%の時は, その正誤差が， $7.4 \mathrm{pH}$ と非常に大きいるのであるが， $\omega \cdot V /\left(F_{0}+F_{1}\right)$ が 10 になると $0.08 \mathrm{pH}$ と急激に小さくなる。こ のことから，1段の制御系でどうしてもよい制御がえられない場 合には，第 2 段に適当な容量の滞留槽を設置することにより，有 効にその $\mathrm{pH}$ 変動を小さくすることが出来ることになる。第 2 段 の滞留槽で $\mathrm{pH}$ 值を測定し，これを第 1 段の調節器にカスケード するかどらかの問題は，その制御系によって決定しなければなら ない。たとえば,・第 1 段の調節器の設定点を調整する必要がある 時は，第 2 段の滞留槽で $\mathrm{pH}$ 值を測定する。

複雑な組成の被調節液の $\mathrm{pH}$ 誤差を求める時は，実際の設計上 の計算には次のよ5にすればよい。すなわち，入力 $\mathrm{pH}$ 変動を， 被調節液の $\mathrm{pH}$ 特性から, 調節隹濃度 $b_{\mathrm{B}}{ }^{\prime}$ あるいは $b_{\mathrm{B}}{ }^{+\prime}, b_{\mathrm{B}}{ }^{-1}$ に換算し（流量変動率が既知ならば，直ちに $b_{\mathrm{s}}{ }^{+\prime}, b_{\mathrm{s}}{ }^{-1}$ がわか る)，また $b_{i} ， V ， F$ は既知なる故，（8）式から心を決めれば， $b^{e}$ s したがって被調節液の $\mathrm{pH}$ 特性から $\left(\Delta \mathrm{pH}^{ \pm}\right)^{\prime}$ がわかる。

これらの関係は，また出力 $\mathrm{pH}$ 誤差 $\left(\Delta \mathrm{pH}^{ \pm}\right)^{\prime}$ を希望値以下に 保つに必要な帯留時間と $\omega$ の関係を示するのである。すなわち, 希望 $\mathrm{pH}$ 誤差を決めれば，それに必要な滞留槽容量を決定するこ とが出来る。

入力值変動の周期は，その系について実験的に求める必要があ るが，大体の目安としては，前段の制御系の全おくれ時間にとれ: ばよい。第 7 図は，以上の計算に必要な計算図表である。

第 7 図 $\frac{b^{e}-b_{\mathrm{s}}}{b_{\mathrm{s}}{ }^{\prime}-b_{\mathrm{s}}}-\omega-\frac{V}{F_{0}+F_{1}}$ の計算図表

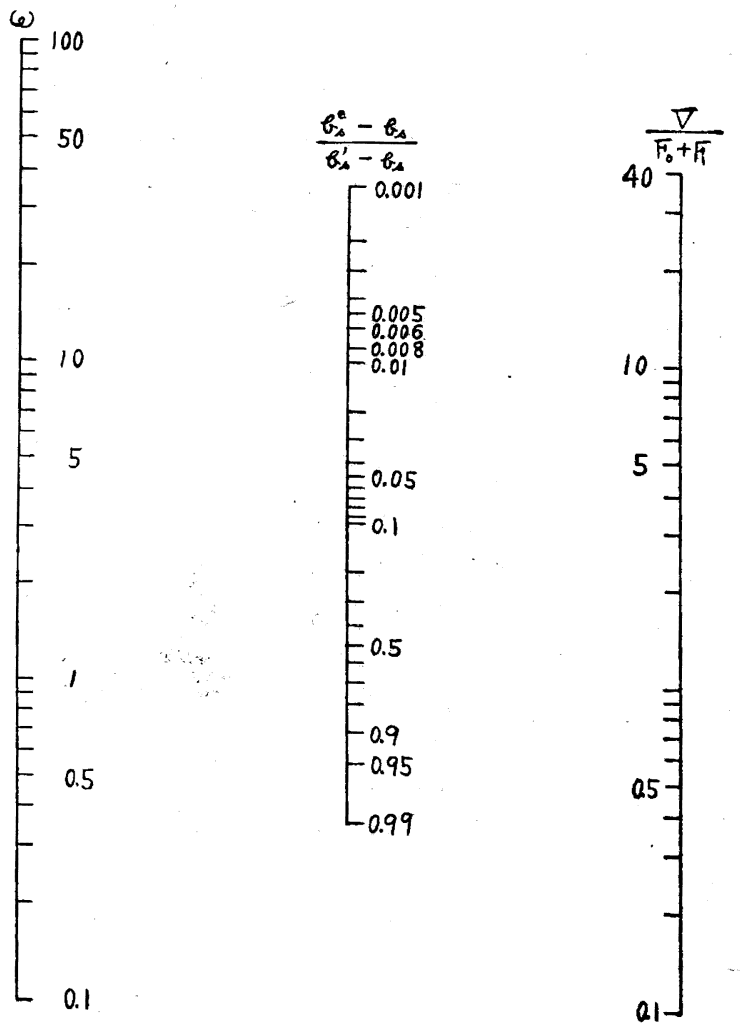

VII. 多段直列滞留槽

次に，単一帯留槽を分割して直列多段にした場合の出力 $\mathrm{pH}$ 4) 岡田, 西, 高橋, 日本計测学会, $\mathrm{pH}$ 部会資料番号 10(1957). 
変化について考察してみる。

(8) 式で, $b_{\mathrm{B}}^{e}-b_{\mathrm{B}}=\Delta b^{e}, b_{\mathrm{B}}{ }^{\prime}-b_{\mathrm{B}}=\Delta b^{\prime},\left\{\omega /\left(F_{0}+F_{1}\right)\right\}^{2}=M$ とおけけば

$$
\Delta b^{e}=\frac{\Delta b^{\prime}}{\sqrt{1+M V^{2}}}
$$

いま, 容量 $V$ なる単一滞留槽を半分に分割し，これを直列 に接続すると，第 1 槽の出力变化 $\Delta b_{1}^{e}$ は

$$
\Delta b^{e}{ }_{1}=\frac{\Delta b^{\prime}}{\sqrt{1+M(V / 2)^{2}}}
$$

第 2 槽の出力変化 $\Delta b_{2}^{e}$ は

$$
\Delta b_{2}^{e}=\frac{\Delta b_{1}^{e}}{\sqrt{1+M(V / 2)^{2}}}=\frac{\Delta b^{\prime}}{\sqrt{\left\{1+M(V / 2)^{2}\right\}^{2}}}
$$

同様に, $n$ 個に分割した場合には，第 $n$ 槽の出力变化 $\Delta b_{n}^{e}$ は

$$
\Delta b_{n}^{e}=\frac{\Delta b^{\prime}}{\sqrt{\left\{1+M(V / n)^{2}\right\}^{n}}}
$$

同様に，一般に $V_{1}, V_{2}, V_{3} \cdots \cdots V_{n}$ なる容量の湍留槽を $n$ 個直列に接続する場合に対して次式が兄られる。

$$
\Delta b_{n}^{e}=\frac{\Delta b^{\prime}}{\sqrt{\left(1+M V_{1}^{2}\right)\left(1+M V_{2}^{2}\right) \cdots\left(1+M V_{n}^{2}\right)}}
$$

また（12），(15）式より $\Delta b^{\prime}$ を消去すると

$$
\frac{\Delta b_{n}^{e}}{\Delta b^{e}}=\sqrt{\frac{1+N}{\left(1+N / n^{2}\right)^{n}}}
$$

ただし

$$
N=M \cdot V^{2}
$$

すなわち（17）式は，滞留槽の全容量が同じ場合に，単一滞留 槽の示す出力値と, 多段滞留槽の示す出力値の関係を示すもので ある。

$\Delta b_{n}^{e} / \Delta b^{e}=1$ の時は，単一槽と多段槽とは同じ効果を示し， $\Delta b_{n}^{e} / \Delta b^{e}>1$ の時は, 単一槽の方が出力値小さく, $\Delta b_{n}^{e} / \Delta b^{e}<1$ の時恃多段槽の方が出力值が小さい。 $n=2,3,4,5$ の時の $\Delta b_{n}^{e}$ l $\Delta b^{e}$ と $N$ の関係を第 3 表に示す。これから, 段数が增えるほど, $\Delta b_{n}^{e} / \Delta b^{e}<1$ になる $N$ の值が大きくなることがわかる。そして $n \rightarrow \infty$ では (17) 式から常に $\Delta b_{n}^{e} / \Delta b^{e}>1$ となる。これは, $n \rightarrow$ ので管路系になることによる。また， $V$ が大きい時には， $N$ が 大きくなる故，これを多段に分割した方が，出力変化が小さくな るが，容量が小さくなると， $N$ が小さくなる故むしろ単一槽の

\begin{tabular}{|c|c|c|c|}
\hline \multirow{2}{*}{$n$} & \multicolumn{3}{|c|}{$\begin{array}{c}\frac{\Delta b_{n}^{e}}{\Delta b^{e}}-N-n \text { の関係 } \\
N\end{array}$} \\
\hline & $\Delta b_{n}^{e} / \Delta b^{e}>1$ & $\Delta b_{n}^{e} / \Delta b^{e}=1$ & $\Delta b_{n}^{e} / \Delta b^{e}<1$ \\
\hline 2 & $<8$ & 8 & $>8$ \\
\hline 3 & $<12.4$ & 12.4 & $>12.4$ \\
\hline 4 & $<16.9$ & 16.9 & $>16.9$ \\
\hline 5 & $<21.4$ & 21.4 & $>21.4$ \\
\hline
\end{tabular}
方が出力変化小となる。この関係は，かきまぜ動力の見地からも 重要なことで，滞留槽の容量を增加すれば， short circuitingを 減少させるために，かきまぜ動力が罯数的増加する。したがっ て，大きな滞留槽扣よびカマキゼ機をつけた系よりる，これを分 割して多段にした方が，費用が安上りで，かつ制御結果もよくな ることになる。

第 8 図は，(13)，(18）式から， $\Delta b_{n}^{e} / \Delta b^{\prime}-N-n$ の関係を計算 したもので，この図から最適段数を決定することが出来る。 たとえば，大きさ $\left\{\begin{array}{l}+3.5 \mathrm{pH} \\ -2.9 \mathrm{pH}\end{array}\right.$ 変動周期 4 分なる $\mathrm{pH}$ 変動が,かな
第 8 図 $\frac{\Delta b_{n}^{e}}{\Delta b^{\prime}}-N-n$ の関倸図

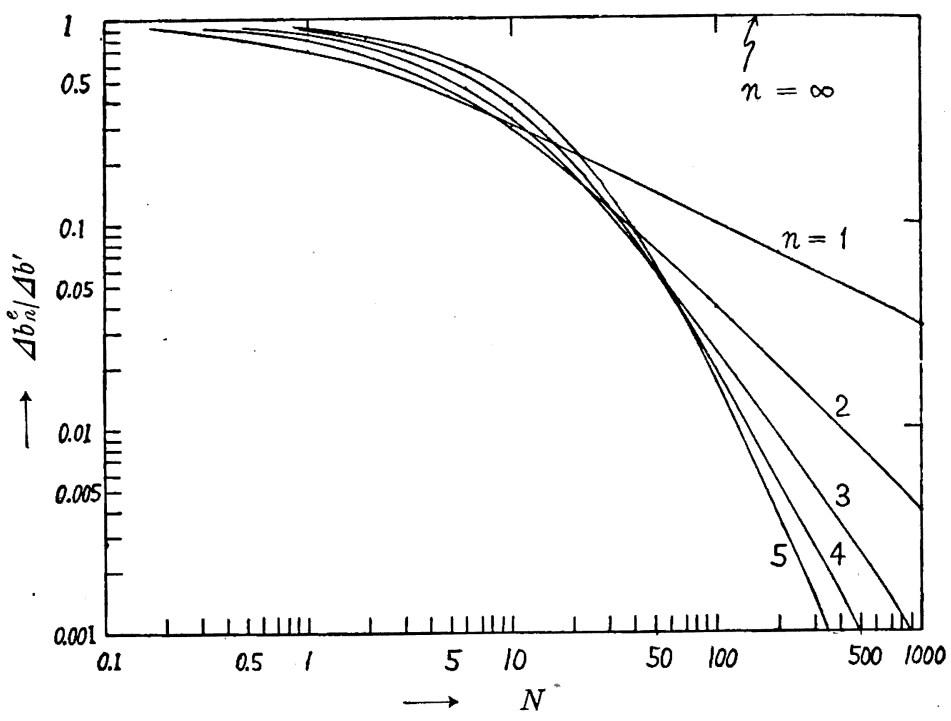

りいちょうな状態で起っており,これを滞留槽の設置によりさ0.1 $\mathrm{pH}$ 以内の変動にする場合について計算してみる。溶液の $\mathrm{pH}$ 変 動は, 酸成分の変動によって起って打り, $\mathrm{pH}$ 性特より $\left\{\begin{array}{l}+3.5 \mathrm{pH} \\ -2.9 \mathrm{pH}\end{array}\right.$ に対する $\pm 0.1 \mathrm{pH}$ の比を酸成分量の比 $\Delta b_{n}^{e} / \Delta b^{\prime}$ 飞换算すると， 0.008 になる。溶液の流量は, 操業状態の関係より $450 \mathrm{l} / \mathrm{min}$ で, いちよらに流さなければならない。滞留槽の谷量は, 設渻場所等 の関係から最大 $5000 l$ である。

これらの条件より,

$$
\left\{\begin{array}{l}
\omega=2 \pi / 4=1.57 \quad(\mathrm{rad} / \mathrm{min}) \\
\frac{V}{F_{0}+F_{1}}=\frac{5000}{450}=11.11 \quad(\mathrm{~min}) \\
N=304.15 \\
\frac{\Delta b_{n}^{e}}{\Delta b^{\prime}}=0.008
\end{array}\right.
$$

となる。したがって，第 8 図より上記の条件を満足する槽数を求 めると, 2 と 3 の間にある。故に, $n=3$ とすれば, $\mathrm{pH}$ 变動を $\pm 0.1 \mathrm{pH}$ 以内に十分留めることが出来る。また，もし，単一槽 のみで, $\pm 0.1 \mathrm{pH}$ 以内に留めるには， $N=15625$ なる故, 約 $35700 l$ の容量が必要で, 3 段槽にくらべ約 7 倍の容量が必要と なる。

この結果から, 設定点の緩衝指数が大きくて，1 段制御系で， 精密な $\mathrm{pH}$ 制御を行うことが出来ない時には，多段制御の有効な ことがわかるであろう。

(昭和 32 年 12 月, 日本計測学会 $\mathrm{pH}$ 部会で講演)

[注] 永田らは，押出比率抽よび，平均混合払散係数なる概念 を導入して，槽内の濃度応答曲線の実験式を提出している。いま 槽内の濃度变化が，むた時間 $L$ 々時定数 $T$ なる指数関数の和で 近似されるるのとすれば，永田の実験式を再配列して

$$
\begin{aligned}
& L=\alpha N^{-2 / 3} \theta \theta^{1 / 3}(H / D)^{4 / 3} \\
& T=\theta\left[1-\alpha(N \theta)^{-2 / 3}(H / D)^{4 / 3}\right]
\end{aligned}
$$

ただし，N=かきまぜ速度， $\theta=$ 滞留時間，H/D=槽高比， $\alpha$ は カキマゼ機の形, 構造により定まる俰数である。

したがって，たと党ば，第(VI)節の取报いに対して，濃度誤差 の大きさのみを問題にする時は, $V /\left(F_{0}+F_{1}\right) \equiv \theta$ の代わりに, $T$ を使用すればよい。 